\title{
NEW RECORD OF INVERTEBRATES ASSOCIATED WITH DECOMPOSED WOOD FROM THE PLAIUL FAGULUI RESERVE
}

\section{Galina Bușmachiu, Svetlana Bacal, Cristian Mînzat, Daniela Burduja}

\author{
Institute of Zoology, Chișinău, Republic of Moldova, e-mail: bushmakiu@yahoo.com
}

Abstract. The paper presents new data about the diversity of invertebrates associated with decomposed wood from the Plaiul Fagului Reserve. A total of 60 invertebrate species belonging to 45 genera, 20 families and two classes Collembola and Insecta (Coleoptera and Hymenoptera) were identified. A rare species - Carabus intricatus and C. ullrichi included in the third edition of the Red Book were highlighted. Four new species of Coleoptera are recorded for the first time for the reserve.

\section{Introduction}

The Plaiul Fagului Reserve is situated in the North - West of the Central Moldavian plateau, $70 \mathrm{~km}$ away from Chisinau - the capital of the country, at approximately $47^{\circ} 17^{\prime} 28^{\prime \prime} \mathrm{N}$ $28^{\circ} 3^{\prime} 16^{\prime \prime} E$ in the Central Region of the Republic of Moldova. This reserve is an important part of the Moldavian protected areas with a total surface of 5,558.7 km2. Many rare species of plants and vertebrate animals are mentioned here, including some Carpathian elements [14].

The invertebrate fauna of the Plaiul Fagului Reserve was studied and the data are published in several papers and books $[3,4,6,14]$. Notwithstanding the studies presented above, a wide range of insects species have not been studied yet, and some large groups have not even been mentioned before this research. The diversity of invertebrates associated with decomposed wood from the reserve has not been studied separately.

The aim of this paper was to reveal the invertebrate species associated with dead woods and to increase the knowledge about insects involved in wood decomposition from the Plaiul Fagului Reserve.

\section{Materials and methods}

The vegetation of the reserve consists of several types of temperate mixed forests typical for the European region. The arboreal vegetation is dominated by the oak, lime, ash and hornbeam. Of the total forested area, $5 \%$ is occupied by beech forest, being the largest territory covered by monodominant beech in the whole country [14]. Several old fallen trees were kept on the territory of the reserve in order to protect rare invertebrate species the life cycle of which is linked to the decomposed wood (fig. 1).

The invertebrates were collected from the decaying wood from the Plaiul Fagului Reserve in October 2020 (sample I) and in March (sample II), April (sample III) and Mai (samples IV and V) 2021. The list of species and number of specimens are included in the Table 1.

Saproxylic beetles and ants were collected manually under the bark or from the dry trees fallen to the ground and from trunks in an advanced degree of decomposition. Supplementary soil and decomposed wood samples were taken for the extraction of small invertebrates (bee- 
tles, ants and collembolans).

Collembola, small beetles (Staphylinidae) and some ant specimens were collected from decomposed wood by exhauster.

The taxonomic identification of invertebrate species was performed using MBS-10, Meiji Techno binoculars and microscope Leica. The modern determination keys specific to each group were used $[1,5,7,10,15]$.

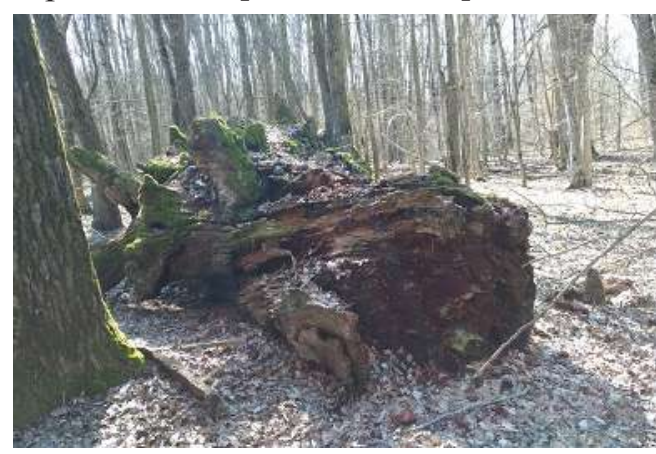

Figure 1. Decomposing trees in Plaiul Fagului Reserve - host of invertebrates

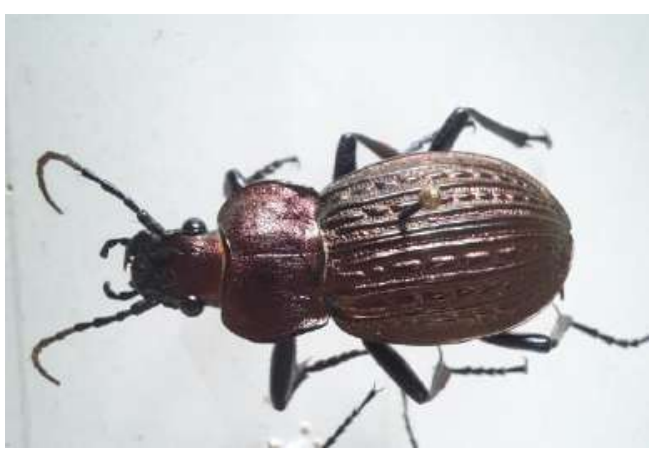

Figure 2. Carabus ullrichii - species included in the Red Book

\section{Results and discussions}

As result of the investigation, new data about the invertebrates associated with decomposed wood from the Plaiul Fagului Reserve were obtained. A total of 60 invertebrate species from two classes (Collembola and Insecta) belonging to 45 genera and 20 families were recorded in the microhabitat formed by decomposed wood in the forest ecosystem (Table 1). For each species a brief information regarding the number of specimens, some data about the ecology is presented.

Four coleopteran species - Litargus connexus, Bolitophagus reticulatus, Pyrochroa coccinea and Thanasimus formicarius were identified for the first time in the reserve. Two identified species Carabus intricatus and C. ullrichii (fig. 2) are rare and included in Red Book of the Republic of Moldova [13].

Table 1. Invertebrates associated with decomposed wood from the Plaiul Fagului Reserve

\begin{tabular}{|c|c|c|c|c|c|c|c|}
\hline \multirow{2}{*}{ Family } & \multirow{2}{*}{ Genus } & \multirow{2}{*}{ Species } & \multicolumn{5}{|c|}{ Sample } \\
\hline & & & I & II & III & IV & $\mathrm{V}$ \\
\hline Odontellidae & Superodontella & $\begin{array}{l}\text { S. montemaceli Arbea\& Wiener, } \\
1992\end{array}$ & - & 2 & - & 1 & - \\
\hline Neanuridae & Thaumanura & T. carolii (Stach, 1920) & - & - & 7 & 21 & - \\
\hline Isotomidae & Isotoma & I. viridis Bourlet, 1839 & & & & 1 & - \\
\hline \multirow{4}{*}{$\begin{array}{l}\text { Entomobry- } \\
\text { idae }\end{array}$} & \multirow[t]{2}{*}{ Orchesella } & O. pseudobifasciata Stach, 1960 & - & - & - & 1 & - \\
\hline & & O. pannonica Stach, 1960 & - & - & - & 1 & - \\
\hline & \multirow[t]{2}{*}{ Lepidocyrtus } & L. lignorum (Fabricius, 1775) & - & - & - & 1 & - \\
\hline & & L. violaceus Lubbock, 1873 & & & & 1 & - \\
\hline
\end{tabular}




\begin{tabular}{|c|c|c|c|c|c|c|c|}
\hline \multirow[t]{3}{*}{ Tomoceridae } & $\begin{array}{l}\text { Pogonog- } \\
\text { nathellus }\end{array}$ & P. flavescens (Tullberg, 1871) & - & 3 & - & 5 & - \\
\hline & \multirow[t]{2}{*}{ Tomocerus } & T. minor (Lubbock, 1862) & - & - & - & 1 & - \\
\hline & & T. vulgaris (Tullberg, 1871) & - & 2 & - & 4 & - \\
\hline \multirow{16}{*}{ Carabidae } & Abax & A. parallelepipedus (Dejean, 1828) & - & - & - & - & 1 \\
\hline & Amara & A. aenea (De Geer, 1774) & 1 & - & - & - & - \\
\hline & Agonum & A. assimile (Paykull, 1790) & 11 & - & & - & - \\
\hline & \multirow[t]{7}{*}{ Carabus } & C. cancellatus Illiger, 1798 & 1 & 4 & - & - & - \\
\hline & & C. convexus Fabricius, 1775 & - & - & 1 & - & - \\
\hline & & C. coriaceus Linnaeus, 1758 & - & - & - & 1 & - \\
\hline & & C. granulatus Linnaeus, 1758 & - & - & - & 1 & - \\
\hline & & C. excellens Fabricius, 1798 & - & - & - & - & 4 \\
\hline & & C. intricatus Linaeus, 1761 & 6 & 3 & - & - & - \\
\hline & & C. ullrihi Germar, 1824 & - & - & - & 1 & - \\
\hline & Panagaeus & P. cruxmajor (Linnaeus, 1758) & - & - & 1 & - & - \\
\hline & Molops & M. piceus (Panzer, 1793) & - & - & - & 1 & 2 \\
\hline & Nebria & N. rufescens (Stroem, 1768) & - & - & - & - & 4 \\
\hline & Notiophilus & N. laticollis Chaudoir, 1850 & - & - & - & - & 1 \\
\hline & Platynus & P. krynickii (Sperk, 1835) & - & - & - & 1 & - \\
\hline & Pterostichus & $\begin{array}{l}\text { P. oblongopunctatus (Fabricius, } \\
\text { 1787) }\end{array}$ & - & - & - & 1 & - \\
\hline \multirow[t]{3}{*}{ Coccinellidae } & Coccinella & $\begin{array}{l}\text { C. septempunctata (Linnaeus, } \\
\text { 1758) }\end{array}$ & 1 & - & 1 & - & - \\
\hline & Propylea & $\begin{array}{l}\text { P. quatuordecimpunctata (Linnae- } \\
\text { us, 1758) }\end{array}$ & 1 & - & - & - & - \\
\hline & Harmonia & H. axyridis (Pallas, 1773) & 1 & - & - & - & - \\
\hline \multirow[t]{4}{*}{ Elateridae } & \multirow[t]{3}{*}{ Ampedus } & A.pomonae Stephens, 1830 & 2 & - & - & - & - \\
\hline & & A.sanguineus (Linnaeus, 1758) & - & 3 & - & - & - \\
\hline & & A. sanguinolentus (Schrank, 1776) & - & - & - & - & 1 \\
\hline & Megapenthes & M. lugens (Redtenbacher, 1842) & 1 & - & - & - & - \\
\hline \multirow[t]{2}{*}{ Geotrupidae } & \multirow[t]{2}{*}{ Geotrupes } & $\begin{array}{l}\text { G. stercorosus Hartmann in Scriba, } \\
1791\end{array}$ & - & - & - & - & 1 \\
\hline & & G. vernalis (Linnaeus, 1758) & - & - & - & 1 & 2 \\
\hline Erotylidae & Triplax & T. aenea (Schaller, 1783) & - & 2 & - & - & - \\
\hline $\begin{array}{l}\text { Mycetophagi- } \\
\text { dae }\end{array}$ & Litargus & *L. connexus (Geoffroy, 1785) & - & 2 & - & - & - \\
\hline Silvanidae & Uleiota & U. planata (Linnaeus, 1761) & 5 & 2 & - & 2 & 3 \\
\hline Scarabaeidae & Cetonia & C. aurata (Linnaeus, 1758) & - & 1 & - & - & - \\
\hline
\end{tabular}




\begin{tabular}{|c|c|c|c|c|c|c|c|}
\hline \multirow[t]{7}{*}{ Staphylinidae } & Aleochara & A. curtula (Goeze, 1777) & - & - & - & - & 1 \\
\hline & Atrecus & A. affinis (Paykull, 1789) & - & 2 & - & - & - \\
\hline & Scaphidium & S. quadrimaculatum Olivier, 1790 & 2 & - & - & 2 & 2 \\
\hline & Sepedophilus & S. marshami (Stephens, 1832) & 1 & 2 & - & - & - \\
\hline & Paederus & P. littoralis Gravenhorst, 1802 & 1 & - & 1 & - & - \\
\hline & Ocypus & O. nitens (Schrank, 1781) & 1 & - & - & - & - \\
\hline & Tachyporus & T. hypnorum (Fabricius, 1775) & - & 1 & - & - & - \\
\hline \multirow[t]{4}{*}{ Tenebrionidae } & Bolitophagus & *B. reticulates (Linnaeus, 1767) & 1 & - & - & - & - \\
\hline & Scaphidema & S. metallicum (Fabricius, 1792 & 3 & - & - & - & - \\
\hline & Stenomax & S. aeneus (Scopoli, 1763) & - & - & - & 2 & - \\
\hline & Uloma & U. culinaris (Linnaeus, 1758) & 3 & - & - & - & 4 \\
\hline Zopheridae & Bitoma & B. crenata (Fabricius, 1775) & - & 2 & - & - & - \\
\hline Pyrochroidae & Pyrochroa & *P. coccinea (Linnaeus, 1761) & - & - & - & 1 & - \\
\hline \multirow[t]{2}{*}{ Lucanidae } & Dorcus & $\begin{array}{l}\text { D. parallelipipedus (Linnaeus, } \\
\text { 1758) }\end{array}$ & - & - & - & - & 1 \\
\hline & Lucanus & L. cervus (Linnaeus, 1758) & - & - & - & 1 & \\
\hline Cleridae & Thanasimus & ${ }^{*} T$. formicarius (Linnaeus, 1758) & - & - & - & - & 1 \\
\hline \multirow{5}{*}{ Formicidae } & Aphaenogaster & A. subterranea (Latreille, 1798) & - & - & 39 & - & - \\
\hline & \multirow[t]{4}{*}{ Lasius } & L. fuliginosus (Latreille, 1798) & 8 & - & - & - & - \\
\hline & & L. emarginatus (Olivier, 1792) & - & - & 36 & 7 & - \\
\hline & & $\begin{array}{l}\text { L. neglectus Van Loon, } \\
\text { Boomsma \& Andrasfalvy, } 1990\end{array}$ & - & 39 & - & - & - \\
\hline & & L. niger (Linnaeus, 1758) & - & - & 49 & 10 & - \\
\hline
\end{tabular}

* - new species for the reserve

The climatic conditions with high humidity during the winter - spring 2020-2021 created optimal conditions that favored the development of a wide range of invertebrates associated with decomposed wood. During material collection, the decomposed wood was soaked with water. While the wood was broken, a large number of invertebrates were observed. Only a few specimens of each species were collected so as not to damage natural decomposition processes.Collembolan species included in the present study are extracted only from wood in an advanced state of decomposition. A total of 10 collembolan species belonging to 7 genera and 5 families were revealed. All these species are considered silvicolous and saproxylophagous, active participants in wood decomposition processes. The increased preference of the species from the families Neanuridae and Odontellidae (genus Superodontella) to the secular trees oaks residues were observed, in which the unique microhabitats invaded by a rich microflora were formed. The species of two genera Thaumanura and Superodontella can be observed only in natural forest habitats, in which the dominant trees are oak. The species Thaumanura carolii is an indicator of natural deciduous forests of Central European type detected in litter and decomposed wood [4]. 
The order Coleoptera was represented by 14 families, 36 genera and 45 species. The most numerous families were Carabidae with 10 and Staphylinidae with 7 species. From the family Carabidae the genus Carabus was represented by 7 species, the other 3 genera were represented by a single species, while the family Staphylinidae was represented by 8 genera with only one species each. They were followed by the families Tenebrionidae with 4 and Coccinellidae with 3 genera and one species of each genus, Elateridae with 2 genera, of which the genus Ampedus was represented by 3 species, and Megapenthes by one species. Family Lucanidae was represented by 2 genera with one species each, while family Geotrupidae was represented by one genus and two species. Other 7 families were represented by one species each (Table 1). Two species Carabus intricatus and Carabus ullrichii are rare, protected by law and included in the 3rd edition of the Red Book [13]. Recent research has highlighted several species of ants associated with decomposed wood. Between them the species Aphaenogaster subterranea is a widely distributed Mediterranean ant species, which mainly inhabits moderately wet and warm deciduous forests, nesting in the ground, under stones, in rotten wood, rarely in litter. They are active at night, but also extremely active during the day, exhibiting aggressive behavior towards common forest species [11].Lasius fuliginosus has a wide distribution in Europe and Asia, is a zoophagous-xylophagous species. Nests of this ant are most commonly found in the stems of old trees, especially oak, sometimes under rocks or even in open ground. The ant queen of L. fuliginosus can behave as a temporary social parasite, taking the place of the queen of other Lasius sp. developing in their own colony, by eliminating the hosts over a period of time [8]. Lasius niger is one of the commonest European species, which occurs in deciduous, coniferous and mixed forests, in gardens and in open meadows. In forests it tends to nest in the trunks of rotten trees. It has a varied diet: insects, nectar from aphids or seeds. The species is active both day and night [12].Lasius emarginatus is a very common species occurring in central and southern Europe, their nests most often is located under rocks in dry places, but also in dry wood. It avoid wet places [12]. The species Aphaenogaster subterranea, Lasius fuliginosus, $L$. emarginatus and L. niger were cited as being present in the Codri Tigheci in 1980 [9]. The ant Lasius neglectus is an invasive species, which appeared in Europe in the late of twentieth century. The species is native to Asia from where it expanded its range, affecting and substituting other species of ants. The nest can be placed under stones or construction waste and under the bark of trees and in the ground [2].In order to protect useful insect species is important to keep decomposed wood in natural forest ecosystems such as the Reserve Plaiul Fagului. Fallen or dead trees have great importance especially for protection of invertebrate fauna. Not all insects found in dead wood are xylophagous, some of them find shelter during the cold period of the year, most of them being zoophagous and contribute to the regulation of phytophagous species in the ecosystem.

\section{Conclusions}

Notwithstanding the long-term research carried out in the Plaiul Fagului Reserve, some new invertebrate species from classes Collembola and Insecta can be still identified and such high invertebrate abundance was observed for the first time. The climatic conditions with high 
humidity during the winter - spring 2020-2021 created optimal conditions that favoured the development of a wide range of invertebrates associated with decomposed wood. The maintenance of intact patches of natural oak-based forests, with enough quantity of decomposed wood covered by moss could improve forest biodiversity. Especially it is important the presence of carabides and ants that consume a large number of forest pests and contribute to the regulation of phytophagous species activity being active zoophages. The presence of the rare species as well as newly identified species, indicate the importance and conservation value of studied microhabitats in the Plaiul Fagului Reserve. The study was performed within the project 20.80009.7007.02.

\section{Bibliography}

1. Arbea J., Weiner W. M. Deux nouvelles espèces européennes de Superodontella (Collembola, Odontellidae). Bulletin de la Société entomologique de France. Paris, France. 1991 (1992). 96(5): 419-425.

2. Artokhin K. S., Ignatova Polina, Kolesnikov S. I., Reshetov A. A. Changes in the fauna of Hymenoptera in the Rostov region and forecast of ecological consequences. Electronic periodical of SFU "Living and Bioinert Systems", 2, http://www.jbks.ru/archive/issue-2/article-6 2013. (Accesed: March 2, 2021).

3. Baban E., Neculiseanu Z. Carabides (Coleotera: Carabidae) from different types of deciduous forests in the scientific reserve of Plaiul Fagului. Muzeul Olteniei Craiova. Oltenia. Studii și comunicări. Știinele Naturii, 2005. 21:107-110.

4. Buşmachiu G. Fauna colembolelor (Hexapoda: Collembola) din Republica Moldova. Căpățină Prinț. Chișinău. 2021. 200 p.

5. Fjellberg A. The Collembola of Fennoscandia and Denmark. Part II: Entomobryomorpha and Symphypleona. Fauna Entomologica Scandinavica. Brill, Leiden, Boston, Köln. 2007. 42. 264 p.

6. Doniţă N., Ursu A., Cuza P., Ticu Lilia, Buşmachiu Galina, Ostafciuc V. Cercetarea ecosistemelor forestiere din Rezervatia Plaiul Fagului. Edit. Universul, Chişinău. 2007. 176 p.

7. Kryzhanovsiy O. Keys to insects of the European part of the USSR. Nauka. Moscow. 1965. 2: $668 \mathrm{p}$.

8. Novgorodova T. Organization of honeydew collection by foragers of different species of ants (Hymenoptera: Formicidae): Effect of colony size and species specificity. European Journal of Entomology, Ceske Budejovice. Czech Republic, 2015. 112(4): 688-697.

9. Poddubny A. G., Likhovidov V. E., Verlan E. T. Peculiarities of the distribution of myrmecofauna in the Codrii of Moldova. Fauna, ecology and physiology of animals. Știința. Chișinău. 1980. $43-47$.

10. Ruta R., Jałoszyński P., Sienkiewicz P., Konwerski S. Erotylidae (Insecta, Coleoptera) of Poland problematic taxa, updated keys and new records. ZooKeys. Sofia, Bulgaria, 2011. 134: $1-13$.

11. Tăuşan I., Bota O. T., Ştefu A.-A., Cravă A. V. Aphaenogaster subterranea (Latreille, 1798) (Hymenoptera: Formicidae) in Romania: new records, distribution and habitat preferences. Brukenthal Acta Musei. Sibiu, România, 2011. 3: 459-64.

12. Wilson E. O. A monographic revision of the ant genus Lasius. Bulletin of the Museum of Comparative Zoology at Harvard College. Harvard University, USA, 1955. 113: 1-201.

13. ***Cartea Roşie a Republicii Moldova. Ed. III, 2015, Chişinău, 492 p.

14. *** Natura Rezervaţiei Plaiul Fagului. Chişinău, 2005, 431 p.

15.***http://antvid.org. (Accesed: February 21, 2021). 